\title{
Using an Urban Snow Cover Composition-Based Cluster Analysis to Zone Krasnoyarsk Town (Russia) by Pollution Level
}

\author{
Alexander Onuchin, Gregory Kofman, Olga Zubareva, Irina Danilova* \\ Sukachev Institute of Forest of the Siberian Branch of the Russian Academy of Sciences, \\ Krasnoyarsk, Russian Federation
}

Received: 24 December 2019

Accepted: 12 February 2020

\begin{abstract}
Pollution level and distribution are among key indicators of townspeople's life quality and accurate pollution estimation and town pollution zoning proceeding from these estimates are, therefore, challenging problems to be solved for big cities with highly developed industries. We carried out an integrated assessment of some pollutants for Krasnoyarsk Town using the 2018 snow cover chemical composition data and zoned the town by pollutant accumulation by cluster analysis. The resulting zoning based on the simultaneous use of pollutant-specific data was visualized using GIS and quantitatively confirmed the general public view of most districts of the town as being extremely adverse ecologically. Unlike most studies, where decisions on pollution zone boundaries are either intuitive, or made out of so-called "general considerations", the cluster analysis-based methodology applied in this study enabled to approach this problem algorithmically, i.e. to avoid a priori assumptions. The analysis we carried out based on the results of our original experimental research approach that involved a uniform methodology of snow sampling and analysis in the lab combined with state-of-the-art methods of data processing and result visualization, revealed snow cover to be an informative recorder and effective tool to obtain a picture of integrated pollution of urban areas.
\end{abstract}

Keywords: snow cover, atmospheric pollution, accumulation, anthropogenic stress, cluster analysis, town zoning

\section{Introduction}

Pollution is among key factors that determine townsmen's life quality and is seriously considered when it comes to people's residence preferences,

*e-mail: tiv80@mail.ru housing cost, house building policy, migration, and other aspects of urban area management. Accurate pollution estimation and town zoning by pollution level based on these estimates are, therefore, challenges to be taken up in big cities with highly developed industries. Krasnoyarsk (56 $1^{\prime} 8^{\prime \prime}$ N, 92 $92^{\circ} 4^{\prime \prime}$ E), Siberia, the town of interest of this study, is, unfortunately, an infamous industrial pollution champion among Russia's largest towns. 
Ecologically focused geochemical studies widely use deposition substrates to determine air pollution level. Snow cover is one of the most appropriate and researcher-friendly depositaries. Falling snow captures, as it has a high sorption capability, considerable aerosol amounts, adsorbs fluorine, sulphur oxides, and heavy metals. Between snowfalls, particulate matter (PM), i.e. dust, accumulates in the snow surface layer and mineral and organic substances are thus stored unchanged in this natural substrate for a long time. Moreover, as snow falls down more slowly than rain, and as the area of a snowflake is larger than that of a raindrop, it is polluted more compared to liquid precipitation [1]. This snow feature enables to identify stable structure of atmospheric precipitation with due regard to landscape, climate, and specificities of industries. In other words, based on snow cover chemical composition and PM amount in snow water, one can calculate actual atmospheric concentrations of elements and PM for the winter season. For places where snow cover is continuous and prevents soil particle occurrence on its surface, solid precipitate substantial and chemical composition becomes a function of atmospheric precipitation. A pollutant precipitation field configuration and intensity are determined, among other factors, by the amount of its emission, time of accumulation, pollution source location, and prevailing wind [2].

Analyzing snow cover chemical composition enables to determine aureoles of various pollutants, to map pollution for a town, and to identify the most threatening pollution sources. Krasnoyarsk is a town of many industries including non-ferrous metallurgy, mechanical and instrument engineering enterprises, thermal, chemical, and giant aluminum plants. According to Russia's Hydro-Weather Service, Krasnoyarsk is among twenty very-high-pollution towns, whose pollution indexes (PI) are 14 points and higher [3]. PI is an integral environment threat indicator calculated as a normalized sum of relative excesses of air pollutant concentrations. This index is described with a scale of points from zero upward; the greater the index, the heavier the pollution.

Using snow cover chemical composition as a pollution indicator reliable as to basing estimation of Krasnoyarsk ecological situation upon is focused on in a monograph by Khlebopros et al. [4], as well as in Strimzha et al. [5], Polikanova and Talovskaya [6], Badmayeva and Zimmerman [7], Demidenko and Vladimirova [8], and Onuchin et al. [9,10]. Similar studies were done in Baikal Region [11, 12], for Severonikel Industrial Complex, the Kola Peninsula, NW Russia [13], Tomsk Town [14, 15], Tumen Town [16] and for many other industrial towns with stable snow cover. Studying snow cover to estimate pollution, particularly traffic impacts, in urban areas attracts nowadays much interest in Scandinavia [17, 18], East European countries [19-25], the USA [26], and China [27].
The general approach in all the above works is to identify and estimate relative the concentration excesses of certain mono-pollutants and to calculate complex PI. In this respect, detailing environmental pollution distribution and determining most threatening pollutants and contamination sources are highly important for sound environment management decision-making.

Town zoning by a pollutant accumulation in the air presents a separate problem. Unfortunately, researchers practice, as a rule, either a rough artificial division with the dividing line coinciding with the boundaries of the administrative districts of a town $[7,8]$, or a priori identification of pollution zones based on "general considerations" [5]. Scientifically justified pollution zoning of a town goes hand in hand with the problem of choice of the sites remotest from industries, whose pollution level could be taken as background. To choose appropriate background pollution sites becomes especially important when the substrate indicating pollution rate has been decided to be snow cover. Indeed, since the current list of maximum permissible concentrations (MPC) does not include all significant snow pollutants and, since a comparison of cumulative concentrations with MPC values is unfeasible, one has to use background pollution values as references and to analyze pollution excesses based on the chosen background pollution level. We carried out an integrated assessment of some pollutants for Krasnoyarsk Town using the 2018 snow cover chemical composition data and zoned the town by atmospheric pollutant accumulations with the help of a cluster analysis. The zoning results were visualized with GIS technologies.

\section{Materials and Methods}

We sampled snow in 2018, in the middle of March, which is the time of the greatest snow amount, with the help of snow coring gauge VS-43. The gauge was $43 \mathrm{~cm}$ high and $50 \mathrm{~cm}^{2}$ in cross section area. Sample plots were selected in Krasnoyarsk and its suburbs to cover a range of pollution levels. To minimize the effect of snow and PM horizontal transport, we took snow samples in parks and forest glades. To eliminate the influence of traffic, sampling points were at least 20-25 m away from roads.

In the lab, Sukachev Institute of Forest, Krasnoyarsk, we selected 48 snow samples and analyzed them using standard methodologies [29-31]. Snow samples were melted at room temperature. Then they were infiltrated using Green Ribbon Paper Filter in order to separate the liquid phase from solid phase of every sample. The snow water filtrate was subject to a chemical analysis. Snow water filtrate $\mathrm{pH}$ was determined with the help of test 206-pH 1 instrument. The contents of aluminum (Al), nickel $(\mathrm{Ni})$, copper $(\mathrm{Cu})$, and lead $\mathrm{Pb})$ were found by atomic absorption spectrometry. F-, $\mathrm{Cl}-, \mathrm{SO}_{4}^{-}, \mathrm{NO}_{2}-$, and $\mathrm{NO}_{3}-$ anion contents were determined by ion chromatography using Dionex ISN 
110 Ion Chromatography System. The contents of the above elements, anions, and PM were measured in mass concentration units, i.e. in $\mathrm{mg} / \mathrm{dm}^{3}$. These results were then converted into amounts per unit area $\mathrm{mg} /$ $\mathrm{m}^{2} /$ season. The conversion involved calculating each chemical accumulation for the winter season using the following formula: $\mathrm{P}=\mathrm{C} * \mathrm{~V} / \mathrm{S}$, where $\mathrm{C}$ is pollutant concentration in filtered snow water, $[\mathrm{mg} / \mathrm{l}]$; $\mathrm{V}$ is snow water volume in a sample, [1]; and $\mathrm{S}$ is snow gauge cross-section area, $\left[\mathrm{m}^{2}\right]$.

The snow pollution point measurements obtained were spatially interpolated by the inverse distance weighting (IDW) method in ArcGIS software (Geostatistical Analyst Module). The interpolation using IDW is based on the assumption that the points disposed close to the point under consideration have greater influence on the predicted value than distant points and weights of each measurement value is, therefore, inversely proportional to the distance between the points under analysis (Deterministic Methods) [32]. Each chemical element was interpolated as a raster layer to the Krasnoyarsk area. The pixels of the raster layers were $100 \times 100 \mathrm{~m}$ each.

Since pollution sources and its rate vary among the town districts, the cloud of points in the attribute space, with each point representing an individual sample, could be expected to be inhomogeneous and could be divided into regions encompassing sites having close concentration values of all pollutants. As we were particularly interested in the cloud internal structure (if such a structure existed at all), from a large arsenal of multivariate statistical methods we chose cluster analysis, among the advantages of which is the absence of statistical limitations due to, for example, data distribution type and sample size.

The data on nine pollutant accumulations were presented as a standard object-attribute matrix, where the rows were sampling points and columns were the variables the corresponding pollutant concentrations. A strong argument in favor of the resulting division was the coincidence between the cloud internal structures obtained by different methods. Guided, among other things, by these considerations, we used two approaches to the problem of identifying town sites homogeneous as to the integrated pollution. To develop a hierarchic classification, we applied Ward's method [33], which is based on minimizing intragroup variance when grouping sampling points at each step. Ward's method is aimed at building a tree diagram, the configuration of which enables to reveal the structure (if at all) of interest by analyzing a distance threshold corresponding to an increase in distances when uniting two previous groups. Similar results were obtained by the method of $\mathrm{k}$-means, where the number of clusters was set to be four $(\mathrm{k}=4)$ and the cluster centers were selected based on the results of the hierarchic classification [33].

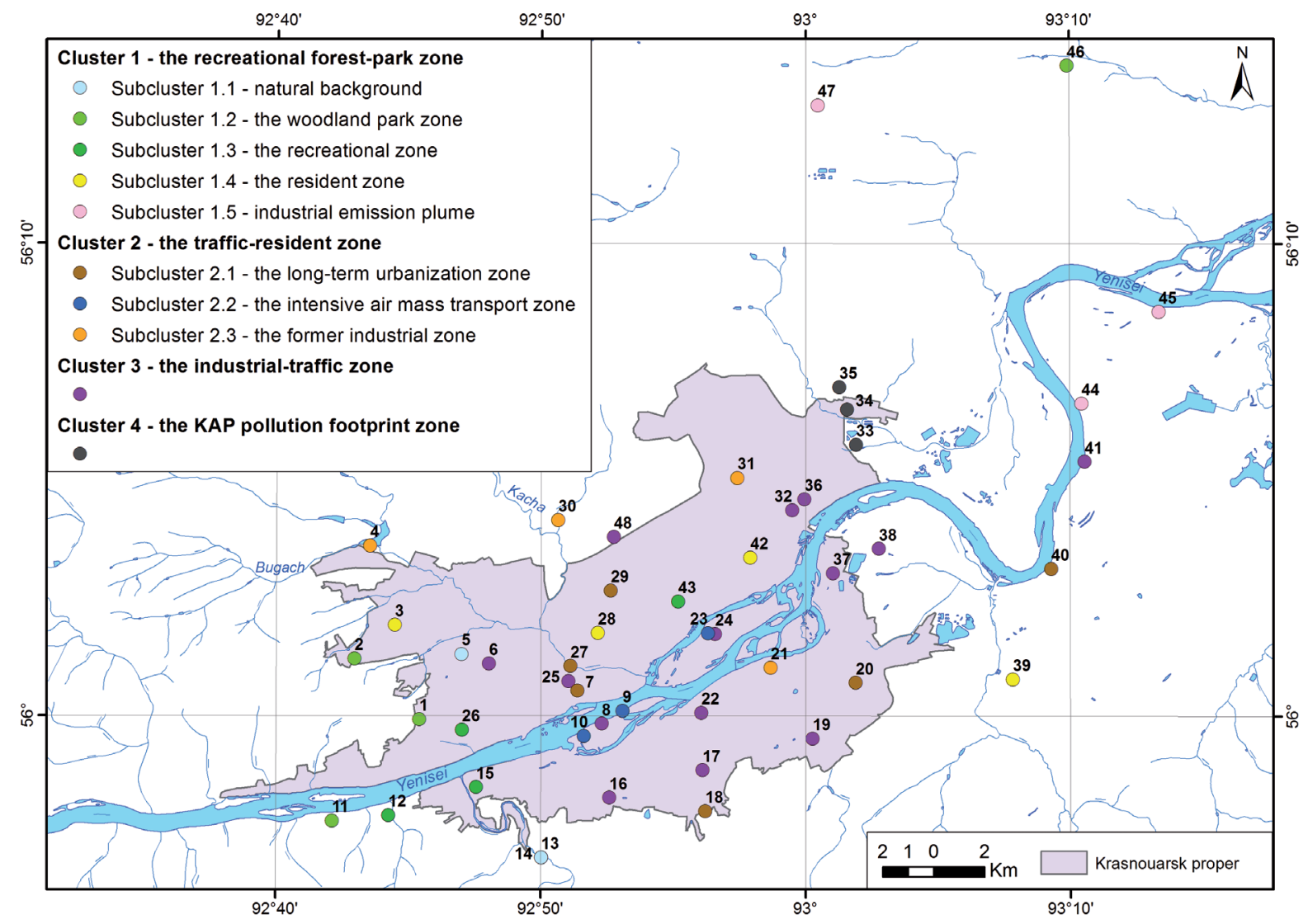

Fig. 1. Snow cover sampling point locations and assignment of the samples studied to clusters. 


\section{Results and Discussion}

As it is clear from the chemical composition of snow water from various districts of Krasnoyarsk and its suburbs (Fig. 1), the accumulations of copper, lead, nitrite-, and nitrate-ions exceeded the conditional background accumulations inconsiderably and were lower than MPCs of these elements accepted for drinking water.

Much greater and even threatening excesses as compared to the background were found for sulfate ions, aluminum, nickel, dust, water-soluble fluorine, and chlorine. Although the accumulations of some of the pollutants varied greatly among the town districts, each anomalous zone was anomalous regarding several pollutants. Within Krasnoyarsk Aluminum Plant (KAP) pollution footprint, for example, we found, along with the expected maximum aluminum accumulation, which was 80 times that of the background (Fig. 2), a bunch of other pollutants whose accumulations appeared to be the highest among the districts studied. PM accumulation in the vicinity of KAP, as well as near Krasnoyarsk Heating and Power Plant 3 (HPP 3) and in the eastern outskirts of the town, showed 80 times increase compared to the background. Nickel and fluorine exceeded their background accumulations 100 and 300 times, respectively, in the emission footprints of KAP, HPP3, and Krasnoyarsk Aluminum Metallurgical Plant (KAMP).
It is noteworthy that, unlike the compact-aureoles pollutants emitted by the above industrial giants, other pollutants exhibited mosaic aureoles that developed for different reasons in different town districts. In the town proper, several aureoles of chlorine ions were recorded (Fig. 3) to show that the pollutant absolute accumulation values and spatial variability were low. The maximum accumulation (concentration) for the winter season and the widest distribution were identified for this pollutant on the eastern bank of the Yenisei River (Sampling Points 37 (City Trees, outskirts (OS)), 38 (Industrial Zone, suburbs (SU)), and 40 (Forest, SU). These accumulation and aureole maximums were presumably related to Heating and Power Plant 1 (HPP-1) emissions and a long-range transport of emissions from HHP-3. Chlorine ions had two small aureoles on the western bank of the river (Sampling Point 25, Park, downtown (DT)).

The results of our study will be used to obtain individual pollutant maps, like those developed for aluminum and chlorine (Figs 2, 3), and will, thus, make it possible to distinguish between clean and anomalous zones and to determine, in some cases, pollution sources. However, the polluted town zones mapped separately even just for two pollutants did not coincide (Figs 2,3) and they will certainly not coincide with a zone for the two pollutants combined. Clearly, the town pollution zoning should be based upon a technical sum of accumulations, because their

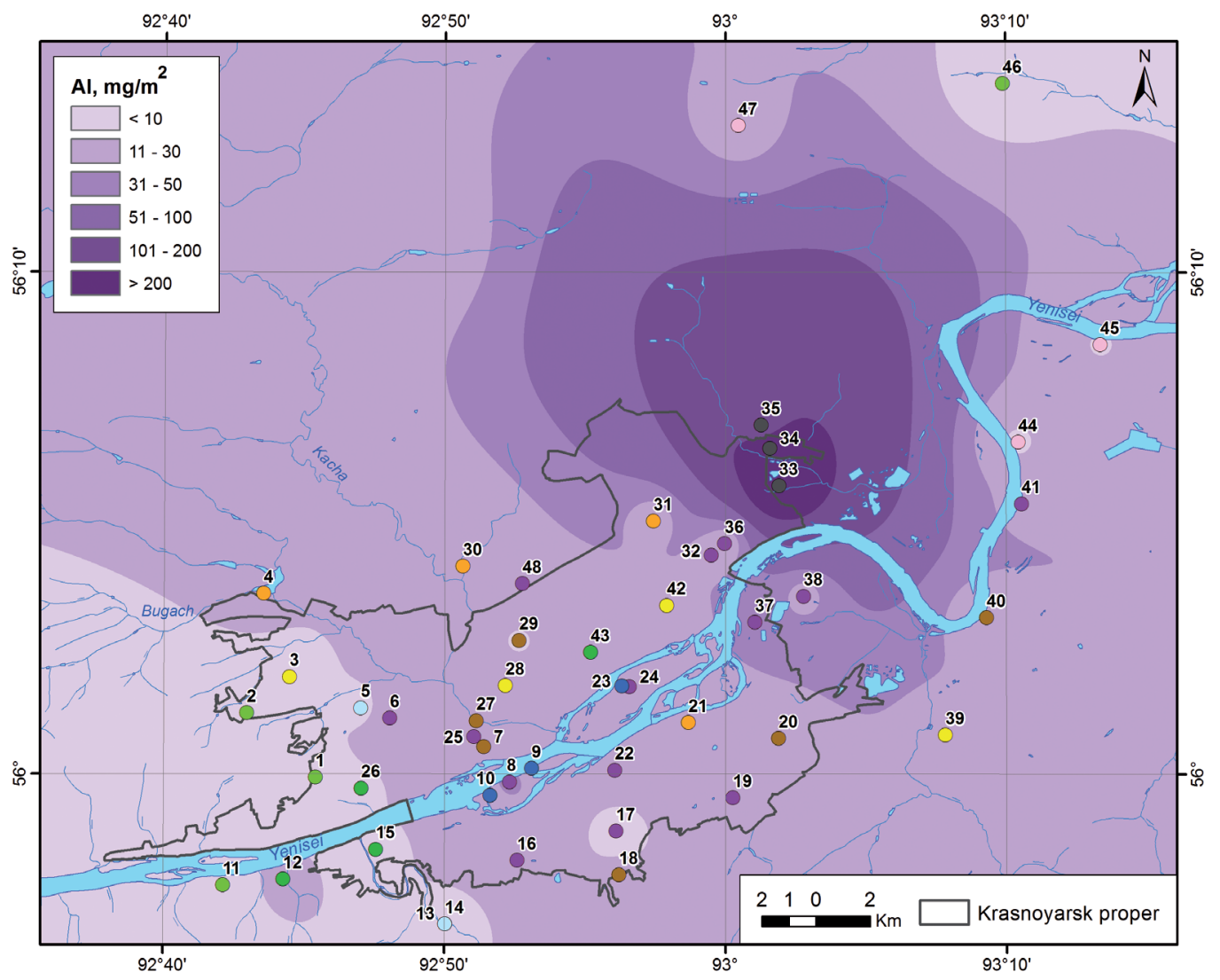

Fig. 2. Compact mono-pollution by aluminum in Krasnoyarsk town. 


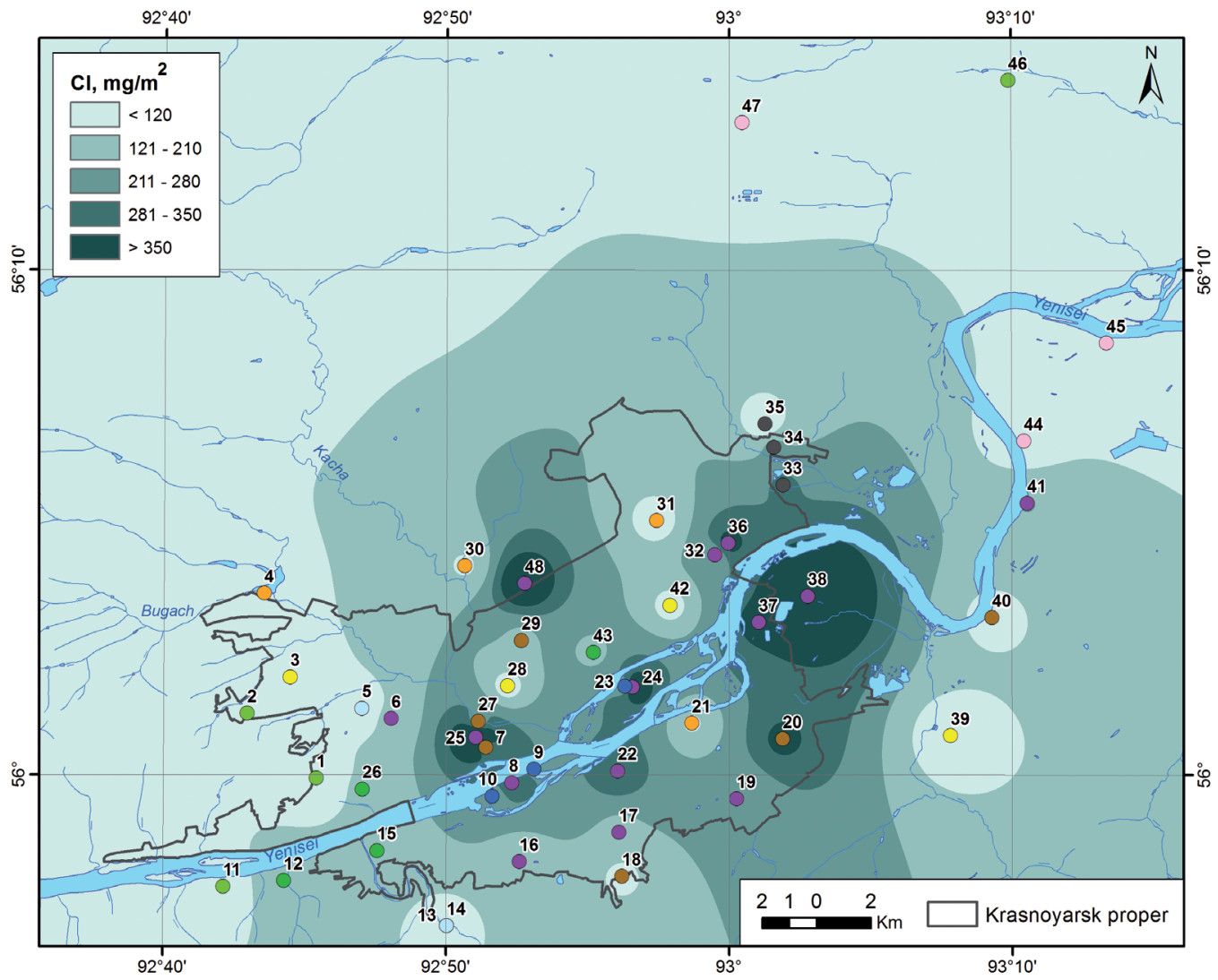

Fig. 3. Mosaic mono-pollution by chlorine ions in Krasnoyarsk.

Tree Diagram for 48 Cases, Ward`s method, Euclidean distansees

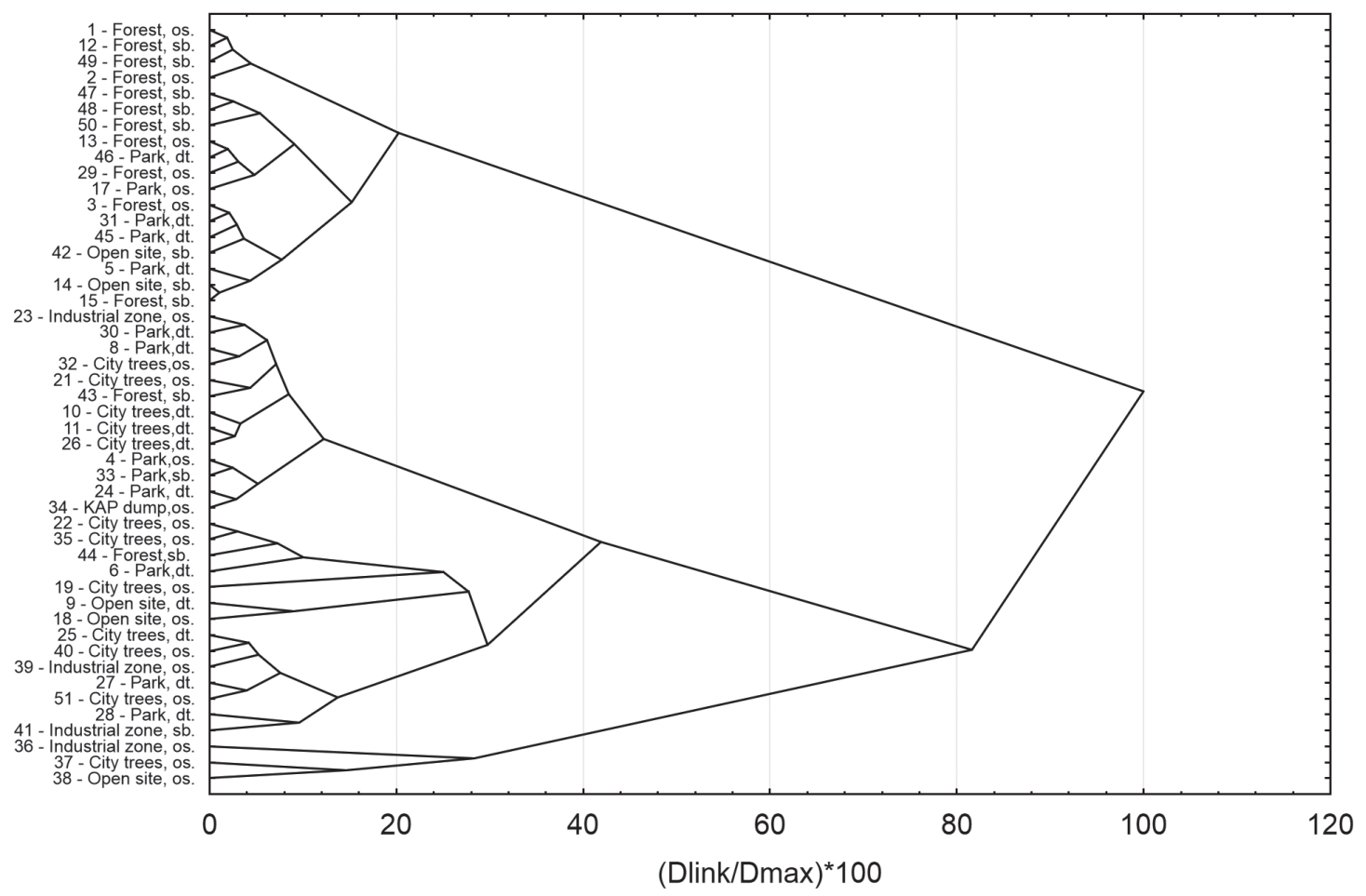

Fig. 4. Hierarchical clustering of Krasnoyarsk area by integrated pollution. Along the abscissa axis are the values of the agglomeration index $\mathrm{k}=\mathrm{D}_{\text {link }} / \mathrm{D}_{\max }$, where $\mathrm{D}_{\text {link }}$ and $\mathrm{D}_{\text {max }}$ are distances for current and final clusters, respectively. Numbers of sampling points (Y-axis) corresponds to Fig. 1, dt stands for downtown, su for suburbs, and os for outskirts. 
Table 1. Variance Analysis.

\begin{tabular}{|c|c|c|c|c|c|c|}
\hline & Between - SS & $\mathrm{df}$ & Within - SS & $\mathrm{df}$ & $\mathrm{F}$ & Signif. - $\mathrm{p}$ \\
\hline $\mathrm{MP}$ & 31.98017 & 3 & 15.01983 & 44 & 31.2282 & 0.000000 \\
\hline $\mathrm{pH}$ & 27.35796 & 3 & 19.64204 & 44 & 20.4281 & 0.000000 \\
\hline $\mathrm{Ni}$ & 38.33331 & 3 & 8.66670 & 44 & 64.8715 & 0.000000 \\
\hline $\mathrm{Al}$ & 43.80848 & 3 & 3.19152 & 44 & 201.3226 & 0.000000 \\
\hline $\mathrm{F}$ & 39.57043 & 3 & 7.42957 & 44 & 78.1158 & 0.000000 \\
\hline $\mathrm{Cl}$ & 22.09648 & 3 & 24.90352 & 44 & 13.0135 & 0.000003 \\
\hline $\mathrm{NO}_{2}$ & 20.40954 & 3 & 26.59046 & 44 & 11.2574 & 0.000013 \\
\hline $\mathrm{SO}_{4}$ & 28.50393 & 3 & 18.49607 & 44 & 22.6025 & 0.000000 \\
\hline $\mathrm{NO}_{3}$ & 18.67756 & 3 & 28.32244 & 44 & 9.6721 & 0.000051 \\
\hline
\end{tabular}

superposition may be an incentive of various types of synergism that can increase the negative impact of the simultaneous presence of several pollutants in the same area. Accomplishing many practical tasks, on the other hand, requires to estimate integrated pollution and to differentiate between individual districts subjected, as a rule, to integrated pollution.

The necessity to simultaneously consider the presence of several pollutants required to use multivariate methods so that our analysis of different aspects of the problem of interest be adequate. As we focused on town zoning by "cleanness", or, more exactly, pollution level, we applied cluster analysis.

The sequence of distinguishing Krasnoyarsk districts homogeneous as to the total range of the pollutants under study is shown in Fig. 4.

Since cluster analysis is, in a way, doomed to success, because the algorithms used always result in object grouping, it was important to prove that the clusters obtained actually existed. In this respect, the hierarchical tree configuration played the key role [33, 34].

The occurrence of many small clusters at the first several steps is a specific feature of Ward's method and it is doubtful that all the subclusters of level 1 obtained at $\mathrm{k}<5$ can be meaningfully interpreted. As is clear from Fig. 4, the formation of the internal cluster structures was, in fact, completed at $\mathrm{k}<30$ and for three of the four final clusters even earlier, at $\mathrm{k}<20$. This picture of the four final clusters was also confirmed by the empirical rule, according to which the number of clusters $n=m^{-1}[33,34]$, where $m$ is sample size and 1 is number of steps until "jump" of distances at sequential grouping of clusters of previous levels. In our case, $\mathrm{m}=48$ and a "jump" occurred at steps 44-45. Therefore, the final was presumably the structure that consisted of four clusters: (1) Sampling Points 1 (Forest, OS) and 14 (Forest, SU); (2) Sampling Points 20 (Industrial Zone, OS) and 31 (KAP Dump, OS); (3) Sampling Point 19 (City Trees, OS).

Essentially the same clustering results were obtained by the divisive method of k-means [33], where the 'centers' of the final clusters obtained by the agglomeration method were chosen to be group centers. In both cases, Ward's method, being among the most statistically sound of all clustering methods and enabling to judge, to a certain extent, the significance of the results, was applied to discriminate homogeneous groups in the attribute space. The method of k-means showed (Table 1) that mean values of all attributes differed significantly among the four final clusters.

The larger were the values of the intergroup sums of squares about the mean for each pollutant accumulation compared to the intragroup sums and, hence, the larger was $\mathrm{F}$ criterion, the greater was the contribution of a variable to cluster discrimination. From this viewpoint, the most informative variables were $\mathrm{Al}$, $\mathrm{F}$, and $\mathrm{Ni}$, whereas $\mathrm{NO}_{3}$ and $\mathrm{SO}_{4}$ exhibited the least cluster discriminating capabilities and more uniform distributions across Krasnoyarsk.

The cluster-averaged accumulations of the pollutants under study are shown in Fig. 5. Regarding Al, F, and $\mathrm{Ni}$ accumulations, the differences among Clusters 1, 2 , and 4 appeared to be negligible in comparison with the difference of each of them from Cluster 3, which is within KAP pollution footprint. Although there were few cases of pairwise coincidence, for example, for $\mathrm{pH}$ and $\mathrm{SO}_{4}$ (Clusters 2 and 3), average accumulations were significantly different in general.

The resulting clusters were conventionally named: Cluster 1 - recreational forest-park zone, Cluster 2 - traffic-resident zone, Cluster 3 - industrial-traffic zone, and Cluster 4 - KAP pollution footprint. Clearly, each of these large four clusters was heterogeneous as to its intrinsic structure. In any case, however, the differences between small clusters within a large one were less significant than those between large clusters in general. Again, we compared distances in the attribute-concentration (accumulation) space, but not the actual geographical closeness of the sites of interest. It was for this reason that, at the first step, Sampling Point 1 (Forest 2, OS) was grouped with Sampling Point 11 (Forest 3, SU), whereas Sampling Point 26 (Forest 7 , OS) was, in the attribute space, closer to Sampling 


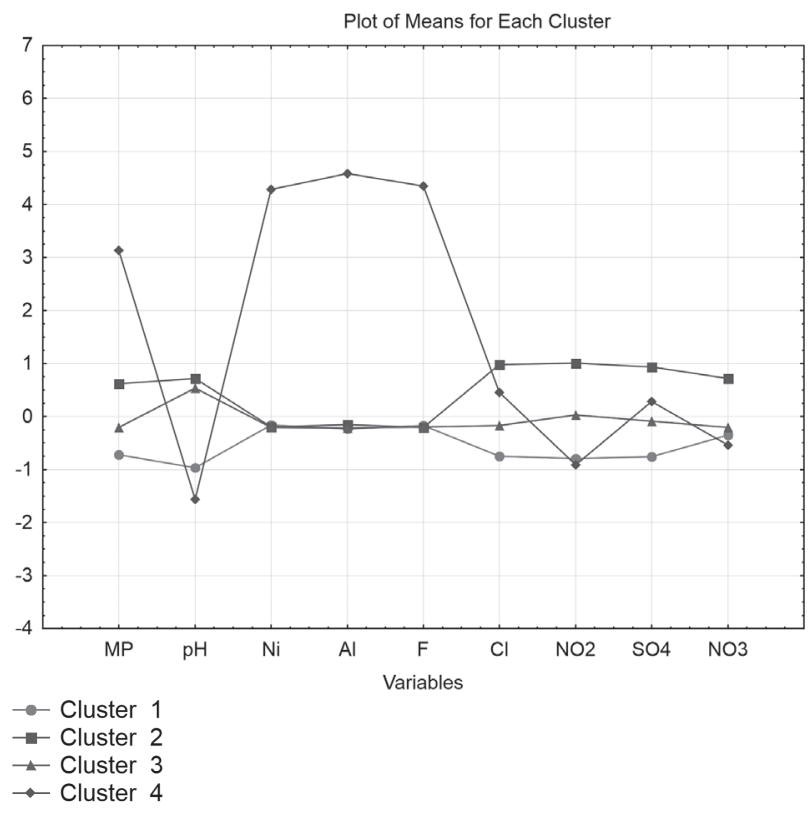

Fig. 5. Cluster-averaged pollutant accumulations.

Points 43 (Park 2, DT) and 12 (Forest 6, OS), although these objects (sampling points) are geographically far apart.

Analyzing the tree diagram in Fig. 4 allowed us to discriminate smaller homogeneous groups, subclusters, in the first two clusters, five and three subclusters, respectively. We decided not to discriminate subclusters for Clusters 3 and 4.

Cluster 1 (the recreational forest-park zone) had the lowest atmospheric pollutant accumulations, because it is remotest from industrial objects and highways. This cluster contained five subclusters: (1.1) natural background, (1.2) the woodland park zone, (1.3) the recreational zone, (1.4) the resident zone (apartment blocks), and (1.5) industrial emission plume.

Subcluster 1.1 (natural background) covered sampling points established in sites found along the western and southwestern boundaries of the town residential zone. These sampling points were adjacent to Stolby Forest Reserve and, due to the prevailing southwestern wind, were least subject to the atmospheric pollution from the town. The mean values of snow water ion and PM accumulation intensity per unit area for the winter season obtained for this subcluster can, therefore, be considered as the regional background pollution level. The average PM accumulation found at the sampling points within this subcluster was $10 \mathrm{mg} / \mathrm{m}^{2} /$ day, which value was close to the background value, $7.0-10.9 \mathrm{mg} / \mathrm{m}^{2} /$ day, mentioned by other authors $[35,36,6]$. The mean background values found in this study for $\mathrm{Al}-, \mathrm{F}-, \mathrm{Cl}$-, and $\mathrm{SO}_{4}$ - ions appeared to be similar to measurements made by other pollution researchers [36-38].

Water-soluble Al ions accumulated to as high as $4.6 \mathrm{mg} / \mathrm{m}^{2}$ during the winter season, nearly twice the background concentration found for Bratsk Town, Baikal Region [36]. In West Siberian Plain, the background $\mathrm{Al}$ concentration ranges 1.6 to $35.5 \mathrm{mcg} / \mathrm{l}$ [39].

The accumulation of water-soluble fluorine averaged $7.74 \mathrm{mg} / \mathrm{m}^{2}(200 \mathrm{mcg} / \mathrm{l})$ for the season, close to the background fluorine $(165 \mathrm{mcg} / \mathrm{l})$ in snow water of Bratsk Town [36].

Ions of $\mathrm{SO}_{4^{-}}$showed an accumulation of $218 \mathrm{mg} / \mathrm{m}^{2} / \mathrm{season}(560 \mathrm{mcg} / \mathrm{l})$, almost twice the background value fond for Stolby Forest Reserve (230 $\mathrm{mcg} / \mathrm{l}$ ), near Krasnoyarsk [4]. In the central taiga zone of Komi Republic, the background $\mathrm{SO}_{4}$ - in snow water is $130 \mathrm{mg} / \mathrm{m}^{2} /$ season [37].

The accumulation of $\mathrm{Cl}$ - ions $\left(46 \mathrm{mg} / \mathrm{m}^{2} / \mathrm{season}\right)$ was 1.5 times the element accumulation in snow water in Stolby Forest Reserve and much higher than central taiga of Komi Republic $\left(21 \mathrm{mg} / \mathrm{m}^{2}\right)$ [37] and the Snezhnaya River basin, Baikal Region [38].

Subcluster 1.2 (the woodland park zone) encompassed popular public forest sites in the town and at the town/ forest interface, in the south- and northwestern parts of Krasnoyarsk. Our analysis of snow samples from these sites revealed a PM accumulation 3 times that in the background. The snow water nickel ion and nitrate ion contents were twice and 4 times, respectively, of the background. The snow water $\mathrm{pH}$ was 5.5 , which was similar to the background value.

Subcluster 1.3 (the recreational zone) grouped together the sites at the northern and southwestern outskirts on the western and eastern Yenisei banks, respectively, and the town public gardens. PM accumulation intensity for the snow cover of these sites showed 5 times increase and the accumulations of nickel and copper ions, aluminum, soluble fluorine, chlorine, sulfate-ions, and nitrate ions in snow water were, respectively, twice, 5 times, triple, twicedouble, and twice those of the background.

Subcluster 1.4 (the resident zone) covered sites mostly in the residential area, except for the central part of the town. PM accumulation intensity here ranged $19.6-80.7 \mathrm{mg} / \mathrm{m}^{2} /$ day, twice to 8 times that of the background. The respective increases in accumulations of nickel ions, aluminum, fluorine, and sulfate-ions in the snow water were 4 times, triple, 4 times, and twice the background.

Subcluster 1.5 (industrial emission plume) was where the woodland park zone had the heaviest snow cover pollution. The measurements at the sampling points of this subcluster that were established beyond the town proper, on the downwind side, indicated a 12 times excess of PM as compared to the background. Nickel ions, aluminum, fluorine, and nitrate- and sulfate-ions exhibited accumulations 5 times, triple, 28 times, and twice those of the background. Sampling Points 44 (Forest, SU) and 45 (Forest, SU) were established in a recreation area along the eastern boundary of the eastern-bank part of the town and experienced the influence of polluted air masses coming with western and southwestern winds from Krasnoyarsk. Sampling 
Point 47 (Forest, SU) was in the north of the town recreational zone and southeastern wind brings KAP emissions to this area.

Cluster 2 was the traffic-resident zone, for which the $\mathrm{PM}$ and ion accumulations in snow water were twice those found for the recreational forest-park zone. In this cluster, we distinguished a long-term urbanization (2.1), intensive air mass transport, along Yenisei (2.2), and former industrial (2.3) subclusters.

Subcluster 2.1 (the long-term urbanization zone) encompassed sites (sampling points) located in the central, eastern, and northeastern parts of the town, which experience pollution caused by vehicles, HPP 1, HPP 3, and various industries. The PM accumulation intensity was determined to range $132-187 \mathrm{mg} / \mathrm{m}^{2} /$ day, $13-18$ times the background value. We observed higher accumulations of nickel ions (twice), aluminum (4 times), fluorine (6 times), and sulfate-ion (4 times) in snow water as compared to the background.

Subcluster 2.2 (the intensive air mass transport zone) included sites (sampling points) located on the Yenisei islands found within the town proper. These sites appeared to suffer somewhat less from PM-caused pollution than the neighboring sites of Subcluster 2.1. The mean value of PM accumulation intensity was 12 times above the background.

Subcluster 2.3 (the former industrial zone) was a group of sites close to former industrial objects, now shut up, and to the areas which are residential today. Snow cover pollution differed insignificantly from the average values we found for the whole of the traffic-resident zone, except for fluoride ions, whose accumulation was $112.9 \mathrm{mg} / \mathrm{m}^{2}$ (vs. $68 \mathrm{mg} / \mathrm{m}^{2}$ for the traffic-resident zone), 15 times the background. This big difference occurred because Subcluster 2.3 covered a part of the former dump of KAP, in the emissions from which fluoride is a major element.

Cluster 3 (the industrial-traffic zone) included, technically, two subclusters having no significant differences in PM and ion accumulations. PM accumulation intensity ranged $154-478 \mathrm{mg} / \mathrm{m}^{2} /$ day, 15-38 times the background value. The accumulations of nickel, aluminum, fluorine, chlorine, sulfate- and nitrate- ions found in snow water were triple, 4, 13, 8, 5 times, and twice those of the background, respectively. In the sites within the highest KAP-caused pollutant accumulation area, however, fluorine was 20-40 times its background accumulation.

Cluster 4 (the KAP pollution footprint zone) covered only three sites situated in the plant sanitary zone. PM accumulation intensity averaged $460 \mathrm{mg} / \mathrm{m}^{2} /$ day. In KAP immediate vicinity, PM accumulation intensity was $810 \mathrm{mg} / \mathrm{m}^{2} /$ day, over 80 times the background. These data agreed with the results of Polikanova's [6] study conducted near KAP. She fixed a PM accumulation intensity of $342-816 \mathrm{mg} / \mathrm{m}^{2} /$ day within one kilometer from the plant. For the three sites, we found that the accumulations of nickel, aluminum and water-soluble fluorine ions in snow water were 100 , 80 , and 300 times those of the background, whereas chlorine, sulfate, and nitrate ions did not exceed those fixed for Cluster 3 (the industrial-traffic zone).

Using snow cover as a recording medium for urban areas is problematic in that this indicator is of a seasonal character and thus cannot be used year round. An apparent solution would be to find a yearround "companion-medium". Moss, for example, could be an appropriate "companion". A study by Salo et al. [40] shows pollutant variables of snow to correlate significantly with those of moss. Moreover, the authors, although they consider both mediums to accumulate pollutants efficiently, suggest that moss be used, even where there is snow, because moss ensures easier sampling control and higher sample homogeneity as compared to snow.

Reverting, for all that, to snow samples, it is worth noting that studies of snow cover pollution use multivariate statistical methods to analyze site-specific pollutant group structures involving identification of the associated pollutants, and, as another task, to classify sites. As for chemometric data processing and result interpretation, the most popular methods, among others, are cluster analysis, principal components method, and multiple correlation-regression analysis. Although heuristic, many of these methods are preferred due to their being flexible and having no restrictions when used, for example, for the measurement scales and data distribution. To underline again, cluster analysis can be applied either to classify objects (sites), in which case variables are element concentrations, or to identify groups of associated elements, which become object with this type of clustering.

The latter clustering type is detailed in Blas et al. [25], where they discuss variable grouping patterns coming from mineral salt impact, impact of secondary emissions and organic pollutants, dissolve matter effects, and human-caused oxidative influences. Shevchenko [39] used the same approach to analyzing snow cover chemical composition and its influence on surface water hydrochemistry in little-studied West Siberian Lowland. He identified groups of elements coming from aluminosilicate mineral matrix, carbonate minerals, and marine aerosols, or belonging to volatile atmospheric heavy metals and liable elements formed by the weathering of minerals.

Identifying related groups and homogeneous sites is, although interrelated, but obviously different problems, solution of which enables to find answers to different questions. In the former case, we develop information on, for example, the structure of the plume from a single emission source, whereas in the latter case it is possible to zone areas based on relative concentrations of pollutants regardless of their chemical nature. Since this study aimed at identifying districts of Krasnoyarsk of homogeneous integer pollution, it was sample plots that were objects, while element concentrations were attributes. 


\section{Conclusions}

Our study of snow cover pollution showed that the background (low) pollution districts are in the western and southwestern parts of Krasnoyarsk Town, whereas the sites around large industrial enterprises, KAP, KAMP, and HPP-3, had PM accumulation 80 times the background value. We determined the ion composition of a snow water filtrate and calculated the ion accumulations for Krasnoyarsk. Aluminum, water-soluble fluorine, and nickel ion accumulations varied most significantly. These high-intensity aureoles occurred around KAP, KAMP, and HPP-3.

The resulting zoning of Krasnoyarsk based on the simultaneous use of pollutant-specific data quantitatively confirmed the current general public view of most districts of the town as being extremely adverse ecologically. Although direct comparisons of the results obtained by different researchers using different methods and recording substrates and based on data collected in different years or simply on analyzing information contained in State Reports [3] are far from being always feasible, the results of many independent studies generally agree among each other as to extremely-high- and background-pollution areas. For example, KAP pollution footprint, unquestionably the dirtiest zone of Krasnoyarsk, showed in our study as a separate cluster coinciding well with the maximum anthropogenic stress area discussed in Khlebopros et al. [4] and Polikanova et al. [6].

Selecting reference sites, zoning the area of the town by integrated pollution in an adequate way, and deciding on the number of these zones was more problematic. Unlike most studies, where this selection and decision are either intuitive, or made out of so-called "general considerations", the cluster analysis-based methodology applied in our study enabled to approach this problem algorithmically, i.e. to avoid a priori assumptions. Clearly, cluster analysis, essentially an exploration method of data analysis, suggests ideas for developing valid hypothesis, rather than provides final answers. It is important, however, that the combined use of the agglomeration (hierarchic) and divisive (k-means) methods enabled, along with clear visualization of the actual existence of the clusters, to estimate the significance of each pollutant contribution to the final clustering that has come of this study.

The analysis we did based on the results of our original experimental research approach that involved a uniform methodology of snow sampling and analysis in the lab and state-of-the-art methods of data processing and results visualization, revealed snow cover to be an informative recorder and effective tool to obtain an adequate picture of integrated pollution of urban areas.

The research was carried out at part of the basic research project of the Sukachev Institute of Forest of the Siberian Branch of the Russian Academy of Sciences (№ 0287-2019-0004).

\section{Acknowledgements}

The authors thank Shapchenkova Olga and Kolosov Roman for his help in carrying out chemical analyses. Also, the authors are much grateful to each other for fruitful intragroup discussions.

\section{Conflict of Interest}

The authors declare no conflict of interest.

\section{References}

1. KASIMOV N.S., KOSHELEVA N.E., VLASOV D.V., TERSKAYA E.V. Geochemistry of snow cover in the eastern district of Moscow. Moscow University Bulletin, Series 5 (Geography). 4, 14, 2012 [In Russian].

2. BORTNIKOVA S.B., RAPUTA V.F., DEVYATOVA YU.A., YUDAKHIN F.N. Methods of analyzing snow cover pollution data in industry impacted zones (A case study: Novosibirsk Town). Journal of Geoecology. Engineering Geology, Hydrogeology and Geocryology. 6, 515, 2009 [In Russian].

3. The 2018 official report on the environment state and protection in Krasnoyarsk Region. Publications of Krasnoyarsk Region Ecology and Natural Resources Ministry. 292, 2019 [In Russian].

4. KHLEBOPROS R.G., TASEYKO O.V., IVANOVA Y.D., MIKHAILUTA S.V. Ecological essays. Publisher: SFU, Krasnoyarsk, Russia. 130, 2012 [In Russian].

5. STRIMZHA T.P., NEUSTROYEVA M.V., PERFILOVA O.YU., FERTIKOV A.I. Estimating air quality in Krasnoyarsk Town by snow cover chemical composition. Krasnoyarsk Teachers' Training College Bulletin. 3, 319, 2012 [In Russian].

6. POLIKANOVA S.A., TALOVSKAYA A.V. Ecological and geochemical conditions in vicinity of Krasnoyarsk aluminum plant as revealed by a snow cover chemical analysis. Material of conference: Rogov Readings: Problems of Engineering Geology, Hydrogeology and Geoecology of Urbanized Territories. Tomsk State University of Architecture and Construction, Russia. 102, 2016 [In Russian].

7. BADMAYEVA S.E., ZIMMERMA V.I. Anthropogenic air pollution in the cities of the Krasnoyarsk Region. Krasnoyarsk Agrarian University Bulletin. 2, 27, 2015 [In Russian].

8. DEMIDENKO G.A., VLADIMIROVA D.S. Estimating human-caused snow cover pollution on the eastern bank of the Yenisei River. Krasnoyarsk Agrarian University Bulletin. 9, 120, 2014 [In Russian].

9. ONUCHIN A.A., BURENINA T.A., ZUBAREVA O.N., TREFILOVA O.V., DANILOVA I.V. Pollution of snow cover in the impact zone of enterprises in Norilsk industrial area. Contemporary Problems of Ecology. 7 (6), 714, 2014.

10. ONUCHIN A.A., BURENINA T.A., DANILOVA I.V., ZUBAREVA O.N. Indication of environmental pollution by industrial emissions in the Arctic latitudes. Materials of conference: Environmental, Industrial and Energy Security, Sevastopol, Russia. 1003, 2017 [In Russian]. 
11. YANCHENKO N.I., SUKHODOLOV A.P., SLUTSKII S.L. Improving the monitoring of the snow cover for emission components from primary aluminum production. Metallurgist. 59, 187, 2015.

12. BELOZERTSEVA I.A., VOROBYEVA I.B., VLASOVA N.V., LOPATINA D.N., YANCHUK M.S. Snow pollution in lake Baikal water area in nearby land areas. Water Resources. 44 (3), 471, 2017.

13. KASHUlinA G., CARITAT P., REIMANN C. Snow and rain chemistry around the "Severonikel" industrial complex, NW Russia: Current status and retrospective analysis. Atmospheric Environment. 89, 672, 2014.

14. TALOVSKAYA A.V., FILIMONENKO E.A., OSIPOVA N.A., LYAPINA E.E., YAZIKOV E.G. Toxic elements $(\mathrm{As}, \mathrm{Se}, \mathrm{Cd}, \mathrm{Hg}, \mathrm{Pb}$ ) and their mineral and technogenic formations in the snow cover in the vicinity of the industrial enterprises of Tomsk. XVIII International Scientific Symposium in Honour of Academician M. A. Usov: PGON2014 IOP Publishing IOP Conf. Series: Earth and Environmental Science 21, 2014.

15. TALOVSKAYA A.V., YAZIKOV E.G., FILIMONENKO E.A., LATA J.C., KIM J., SHAKHOVA T.S. Characterization of solid airborne particles deposited in snow in the vicinity of urban fossil fuel thermal power plant (Western Siberia). Environmental Technology. 39 (18), 2288, 2018.

16. VIALKOVA E., ZEMLYANOVA M., VOROTNIKOVA A., CHERKASHIN D., VORONOV A., MAKSIMOV L. The protection of urban areas from surface wastewater pollutions. MATEC Web of Conferences. 106, 2017.

17. MOGHADAS S., PAUS K.H., MUTHANNA T.M., HERRMANN I., MARSALEK J., VIKLANDER M. Accumulation of traffic-related trace metals in urban winter-long roadside snowbanks. Water, Air \& Soil Pollut. 226, 404, 2015.

18. KUOPPAMAKI K.., SETALA H., RANTALAINEN A-L., KOTZE D.J. Urban snow indicates pollution originating from road traffic. Environmental Pollution. 195, 56, 2014.

19. FRANCOVA A., CHRASTNÝ V., SILLEROVA H., VÍTKOVA M., KOCOURKOVA J., KOMAREK M. Evaluating the suitability of different environmental samples for tracing atmospheric pollution in industrial areas. Environmental Pollution. 220, 286, 2017.

20. ADAMIEC E., WIESZALA R., STRZEBOŃSKA M., JAROSZ-KRZEMISKA E. An attempt to identify traffic related elements in snow. Geology, Geophysics \& Environment. 39 (4), 317, 2013.

21. MARSALEK R. Analysis of dust particles in snow cover in the surroundings of the city of Ostrava: article size distribution, zeta potential and heavy metal content. Int. Journal of Chemical, Molecular, Nuclear, Materials and Metallurgical Engineering. 8 (12), 2014.

22. SIUDEK P., FRANKOWSKI M., SIEPAK J. Trace element distribution in the snow cover from an urban area in central Poland. Environ Monit. Assess. 187:225, 2015.

23. MIHAILOVIĆ A., VASIĆ M.V, NINKOV J., ERIĆ S., RALEVIĆ N.M., NEMEŠ T., ANTIĆ A. Multivariate analysis of the contents of metals in urban snow near traffic lanes in Novi Sad, Serbia. J. Serb. Chem. Soc. 79 (2), 265, 2014.

24. PILECKA J., GRINFELDE I., VALUJEVA K., STRAUPE I., PURMALIS O. Heavy metal contamination and distribution in the urban environment of Jelgava. Research for rural development. 1, 173, 2017.
25. BŁAŚ M., POLKOWSKA Z., SIMEONOV V., TSAKOVSKI S, SOBIK M., KOZAK K., NAMIEŚNIK J. Application of chemometric analysis to the study of snow at the Sudety mountains, Poland. Ecol. Chem. Eng. S. 23 (4), 621, 2016.

26. CARLING G.T., FERNANDEZ D.P., JOHNSON W.P. Dust-mediated loading of trace and major elements to Wasatch Mountain snowpack. Science of the Total Environment. 432, 65, 2012.

27. XUE B-X., WEI L., LI C-Y., LI T-Y. A study of the distribution and composition of pollutants in snow collected from streets and a treatment system for recycling snow in winter cities. Desalination and Water Treatment. 54, 4-5, 1470, 2015.

28. BADMAYEVA S.E., ZIMMERMA V.I. Anthropogenic air pollution in the cities of the Krasnoyarsk Region. Krasnoyarsk Agrarian University Bulletin. 2, 27, 2015 [In Russian].

29. Guidelines on estimating air pollution by metals in settlements based on snow cover metal concentrations. Institute of Mineralogy, Geochemistry, and Crystal Chemistry of Rare Elements (IMGRE) Publications, Moscow, Russia. 16, 1990 [In Russian].

30. Quantitative chemical analysis of water. An atomic absorption spectroscopy. Method to measure aluminum, barium, beryllium, vanadium, ferrum, cadmium, cobalt, lithium, manganese, copper, molybdenum, arsenic, nickel, tin, lead, selenium, strontium, titanium, chrome, and zinc mass concentrations in natural and waste water using MGA-915 atomic absorption spectrometer with electrothermal atomization. Moscow, Russia. 35, 2009 [In Russian].

31. VASILENKO V.N., NAZAROV I.M., FRIDMAN SH.D. Monitoring snow cover pollution. Gidrometeoizdat Publishing House, Leningrad, Russia, 182, 1985 [In Russian].

32. SETIANTO A., TRIANDINI T. Comparison of kriging and inverse distance weighted (IDW) interpolation methods in lineament extraction and analysis. J. SE Asian Appl. Geol. (1), 21, 2013.

33. EVERITT B. S., LANDAU S., LEESE M., STAHL D. Cluster Analysis 5rd ed. Wiley series in probability and statistics. John Wiley \& Sons, Ltd. 330, 2011.

34. CHUBUKOVA I.A. Data Mining.- National Open University "INTUIT.RU”. 471, 2016 [In Russian].

35. YAZIKOV E.G. Ecology and geochemistry of urban areas of southwestern Siberia. The Abstract of the PhD Thesis, Tomsk, Russia. 47, 2006 [In Russian].

36. IGNATENKO O.V., SENCHENKO M.V., MESHCHEROVA N.A. Zoning Bratsk town resident area by snow cover pollution level. Systems Methods and Technologies Journal. 3 (15), 138, 2012 [In Russian].

37. VASILEVICH M.I., BEZNISIKOV V.A., KONDRATENOK B.M. Snow cover chemical composition in the taiga zone of Komi Republic. Journal of Water Resources. 4, 494, 2011 [In Russian].

38. SOROKOVIKOVA L.M., SINYUKOVICH V.N., NETSVETAYEVA O.G., TOMBERG I.V., SEZKO N.P., LOPATINA I.V. Chemical composition of snow and stream water on the southeastern coast of Lake Baikal. Journal of Meteorology and Hydrology. 5, 71, 2015 [In Russian].

39. SHEVCHENKO V.P., POKROVSKY O.S., VOROBYEV S.N., KRICKOV I.V., MANASYPOV R.M., POLITOVA N.V., KOPYSOV S.G., DARA O.M., AUDA Y., SHIROKOVA L.S., KOLESNICHENKO L.G., ZEMTSOV V.A., KIRPOTIN S.N. Impact of snow deposition on major 
and trace element concentrations and elementary fluxes in surface waters of the Western Siberian Lowland across a $1700 \mathrm{~km}$ latitudinal gradient. Hydrol. Earth Syst. Sci. 21, 5725, 2017.
40. SALO H., BERISHA A-K., MÄKINEN J. Seasonal comparison of moss bag technique against vertical snow samples for monitoring atmospheric pollution. Journal of Environmental Science. 41, 128, 2016. 